\title{
PISANIE O PRACY AKADEMICKIEJ
}

\author{
Joss WINN
}

PRZELOŻYE KRYSTIAN SZADKOWSKI

\begin{abstract}
Abstrakt: Niniejszy tekst wzywa do powrotu do teorii pracy rozwijanej przez Marksa, czy raczej do Marksowskiej negatywnej krytyki pracy oraz jej „decydującej” roli w rozumieniu ekonomii politycznej szkolnictwa wyższego. Autor twierdzi, że krytyka kapitalizmu i jego pozornej złożoności musi zostać podjęta w oparciu o bezpośrednią krytykę pracy, nie zaś z punktu widzenia pracy, jak miało to miejsce zarówno w marksistowskich, jak i niemarksistowskich badaniach nad pracą. Przyglądając się egzemplarycznym artykułom poświęconym „pracy akademickiej”, niniejszy artykuł zwraca uwagę na fundamentalne znaczenie stosowania Marksowskiej metody abstrakcji w celu zrozumienia konkretnego społecznego świata kapitału. Na koniec sugeruje, że przyszłość pracy akademickiej leży raczej w jej zaprzeczeniu i przekroczeniu niż w wysiłkach mających na celu oparcie się „logice” pomnażania wartości.
\end{abstract}

Słowa kluczowe: Marks, abstrakcja, metoda, praca, negatywna krytyka 
W liście do Engelsa z 24 sierpnia 1867, to jest roku wydania pierwszej księgi Kapitału, Marks pisał następująco:

Najlepsze w mojej książce jest: 1. uwypuklenie zaraz w piernssym rozdziale dwoistego charakteru pracy w zależności od tego, czy wyraża się ona w wartości użytkowej, czy też w wartości wymiennej (na tym opiera się wszelkie rozumienie facts); 2. rozpatrywanie wartości dodatkowej niezależnie od jej szcrególmych form, jak zysk, procent, renta gruntowa itd. Wystapi to zwłaszcza w drugim tomie (Marks 1975, 397).

„Dwoisty charakter pracy” został przez Marksa po raz pierwszy wyjaśniony w Prayczynku do krytyki ekonomii politycznej (Marks 1966), a następnie przepracowany siedem lat później w pierwszym rozdziale pierwszej księgi Kapitału. To właśnie tam ujawnia on swoje nowe odkrycie naukowe, które uznał za „oś, dokoła której obracają się wszystkie zabiegi ekonomii politycznej" (Marks 1968, 153).

Marksowskie odkrycie ukazuje sposób, w jaki rola, charakter oraz miara pracy stanowią kwestie centralne dla ekonomii politycznej, a zatem również i dla całościowej „logiki” kapitalistycznego świata społecznego. Polegało ono nie tyle na uznaniu pracy za użyteczną i wymienialną tak, jak inne towary, ale na tym, że jej charakter zostaje „wyrażony” i „zawarty” $\mathrm{w}$ formie innych towarów. Wyrażone zostaje to, że praca w kapitalizmie przybiera zarówno formę konkretna, fizjologicznej pracy, jak i postać abstrakcyjna, społecznej homogenicznej pracy. To właśnie abstrakcyjny charakter pracy jest źródłem społecznego bogactwa (tj. wartości) i to on wskazuje na uwspółmierniający sposób szacowania wartości towarów, a zatem bogactwa społeczeństw kapitalistycznych. Marks nazwał tę miarę „społecznie niezbędnym czasem pracy" pisząc, że:

Społecznie niezbędny czas pracy jest czasem pracy potrzebnym do wytworzenia jakiejś wartości użytkowej w istniejących społecznie normalnych warunkach produkcji i przy społecznie przeciętnym stopniu umiejętności i intensywności pracy (Marks 1968, 44).

Prawdopodobnie od czasu ukazania tej „osi, dokoła której obracają się wszystkie zabiegi ekonomii politycznej" nie dokonano żadnych dalszych naukowych odkryć odnośnie fundamentalnego charakteru pracy, który 150 lat temu został rozjaśniony przez Marksa. Harry Braverman podkreślal ten fakt w latach siedemdziesiątych XX wieku stwierdzając, że „w tradycji marksistowskiej nie istnieje żadne dzieło, które podejmując kwestię kapitalistycznego sposobu produkcji wykraczałoby poza ujęcie, przy pomocy którego Marks potraktował ją w swojej pierwszej księdze Kapitału” (Braverman 1998, 7). W istocie jednak, gdy czytam artykuły i książki dotyczące mojej własnej pracy, to znaczy „pracy akademickiej”, fundamentalne odkrycie Marksa wydaje się być wciąż w dużej mierze zapoznane lub wyparte. Co więcej, dzieje się tak pośród przedstawicieli zawodu, od których spodziewałbym się jego pełnego zrozumienia. Najczęściej badania nad pracą akademicką dotyczą obszaru „warunków 
akademickiego zatrudnienia" (academic work), to znaczy zmieniającego się charakteru naszego zawodu (Smyth 1995; Tight 2000; Fitzgerald i in. 2012), wpływu polityki i biurokracji na warunki naszego zatrudnienia (work) (Slaughter i Leslie 1999), polityki miejsca pracy (Martin 1998) oraz, coraz częściej, troski o naszą tożsamość, to znaczy to, co w subiektywny sposób oznacza samo bycie akademikiem (Herman i Schmid 2003; Barcan 2013; Whitchurch i Gordon 2010). Tego rodzaju podejście wychodzi głównie naprzeciw rozpoznanemu już pogorszeniu się warunków pracy akademickiej (academic labour) na całym świecie oraz coraz bardziej zinstrumentalizowanej roli przypisywanej szkolnictwu wyższemu w gospodarkach poszczególnych krajów (Molesworth i in. 2010; Shattock 2012; Brown i Carasso 2013). Natomiast, pomimo stale powtarzanych wezwań do zwiększenia wysiłków na rzecz uzwiązkowienia (Johnson i in. 2003; Krause i in. 2008; Mattson 2000; Nelson 1997), kierunek zmian jest ten sam: indywidualna autonomia zostaje ograniczona (Wilson 1991; Willmott 1995; Hall 2013), warunki zawieranych umów pogarszają się (Cross, Goldenberg 2009; Bérubé 2013; UCU 2013), coraz częściej podnosi się kwestię problemów zdrowia psychicznego (Klinman i Wray 2013), a praca ulega stałej intensyfikacji (Bryson 2004; Gill 2009; Ogbonna i Harris 2004). Spoglądając wstecz, możemy swobodnie dostrzec, w jaki sposób zdobycze dwudziestowiecznego ruchu pracowniczego ulegaja rozkładowi, a w związku z tym mamy również szansę zadać sobie pytanie o to, czy krytyczne narzędzia badawcze rozwinięte przez współczesnych akademików nadają się do zrozumienia tego, co się z nami, jako profesja, rzeczywiście dzisiaj dzieje.

W związku z tym, choć uznaję, że przez kilka ostatnich dekad naukowcy krytycznie pisali o swojej profesji, tworząc liczne monografie, zbiory pod redakcją czy numery czasopism (w szczególności w Workplace: A journal for academic labour`) poświęcone analizowaniu procesu i warunków pracy wewnątrz akademii, to pomimo tego, że wiele już napisano na temat samych warunków zatrudnienia akademickiego (work), mamy wciąż niewiele dzieł, które angażowałyby się istotnie w badanie pracy (labour), jako obiektu krytyki. Wydawałoby się, że to ,unikanie pracy” (labour) (Neary i Dinerstein 2012: 25) rozumianej przedmiot krytycznego badania w naukach społecznych, a nie tylko w studiach nad profesją akademicka, jest czymś wręcz powszechnym. Zamiast krytycznego zaangażowania w analizę kategorii pracy (labour), większą uwagę poświęcono warunkom pracy oraz wynikającej z nich „korozji charakteru” (Sennett 2007). Jak niegdyś stwierdził znakomity historyk Moishe Postone, to właśnie wskutek takiego podejścia mamy do czynienia z niedialektycznym oporem względem otaczających nas materialnych warunków oraz wszechogarniającym poczuciem bezradności (Postone 2006).

\footnotetext{
${ }^{1}$ Niniejszy artykuł został pierwotnie opublikowany w czasopiśmie Workplace: A journal for academic labour, czasopiśmie założonym przez Marca Bousqueta i Kenta Pucketta w 1998 roku, na fali strajków pracowniczych i doktoranckich w sektorze szkolnictwa wyższego, które przetaczały się przez USA w latach dziewięćdziesiątych XX wieku. Zob. http://ices.library.ubc.ca/index.php/workplace/about (przyp. tłum).
} 
W odpowiedzi na to zjawisko, w niniejszym tekście wzywam do powrotu do Marksowskiej teorii pracy, czy raczej Marksowskiej negatywnej krytyki pracy oraz do uwypuklenia jej roli w ekonomii politycznej kapitalizmu. W dalszej części bazuję nie tylko na dorobku Marksa, ale jestem również zadłużony względem jego Postone’owskiej lektury zawartej w przełomowej książce Time, Labour and Social Domination (oraz innych dzieł tego autora), która odnowiła nasze rozumienie roli i charakteru pracy w kapitalizmie, wskazując na fundamentalny błąd w stanowiskach zajmowanych przez działaczy pracowniczych i „studia nad pracą” w ogóle. Twierdzę mianowicie, że krytykę kapitalizmu i jego pozornej złożoności należy przedsięwziąć w oparciu o bezpośrednią krytykę pracy (of labour) raczej niż podejmować ja z perspektymy pracy, jak miało to miejsce w tradycji badań nad praca, niezależnie od tego, czy były one marksistowskie, czy nie. Jak podsumował to Postone: „zarówno konkretny, jak i abstrakcyjnie społeczny wymiar pracy w społeczeństwie kapitalistycznym są według Marksa wymiarami kapitału; żaden $\mathrm{z}$ nich $\mathrm{w}$ ich istniejącej postaci nie reprezentuje horyzontu przyszłości” (Postone 1993, 358). W istocie, uważam, że dwoisty charakter pracy musi zostać zniesiony, przekroczony i pokonany, raczej niż uświęcony i podtrzymany.

W celu ugruntowania tego podejścia w niniejszym artykule chciałbym nakreślić odmienną metodę pisania, a zatem i myślenia o pracy akademickiej, taka, która wychodzi od rygorystycznego zaangażowania w fundamentalne kategorie teorii Marksowskiej oraz od przypisania większego znaczenia metodzie, którą zastosował w celu rozwinięcia tych kategorii. W ten sposób chciałbym jednoznacznie potwierdzić użyteczność Marksowskich spostrzeżeń dla studiowania warunków zatrudnienia (work) związanych z badaniem, kształceniem i uczeniem się, jak również dla ekonomii politycznej szkolnictwa wyższego jako takiej. Postrzegając uniwersytet jako kapitalistyczną instytucję, chciałbym skierować innych naukowców w stronę Marksowskiej „krytyki totalnej”, podejścia, które jest „jednocześnie metodologiczne, teoretyczne i polityczne” (Clarke 1991, 51). Wszystko to w momencie, w którym, jak sądzę, mamy do czynienia z rosnącym zamętem i zafałszowaniem sposobu, w jaki (i czy w ogóle) „praca niematerialna”, „praca intelektualna”, „praca oparta na wiedzy”, „kapitalizm kognitywny”, „praca cyfrowa” różnią się zdecydowanie od pracy pojmowanej przez Marksa (Dyer-Witheford 2005; Harvie i De Angelis 2009; Haug 2009; Peters i Bulut 2011; Scholz 2013; Fuchs 2014).

W obliczu przytłoczenia przez rzeczywiste i złożone warunki naszej pracy jedna z możliwych reakcji jest ich jeszcze mocniejsze urzeczowienie, a tym samym rezygnacja z rygorystycznej analizy w oparciu o prostsze abstrakcyjne kategorie. Niebezpieczeństwo takiego podejścia polega na dalszym hipostazowaniu tego, co już jawi się jako rzeczywiste i konkretne, oraz na konsekwentnym opisywaniu cech kapitalizmu, czy częściej „neoliberalizmu”, zgodnie ze sposobem, w jaki rzeczy jawiq sie, raczej niż poprzez jego bardziej podstawowe społeczne kategorie. W efekcie ulegamy fetyszyzmowi, który uderza we wcielenia 
danych form społecznych, pozostawiając jego bardziej fundamentalny, abstrakcyjny charakter nietkniętym (Postone 1980, 111). W konsekwencji piszemy o tym, co jawi się jako kryzys akademickich warunków zatrudnienia (work), o tak zwanej performatywności pracy, jej prekarności, tayloryzacji, czy w ogólności pogwałceniu jej przez różnorodne neoliberalne technologie. W następnym kroku chciałbym wobec tego skupić się na jednym z często przytaczanych w tym kontekście przykładów.

\section{Wykonywanie pracy akademickiej²}

W swoim tekście zatytułowanym „The Teacher's Soul and the Terrors of Performativity”, Stephen Ball (2003) zdefiniował „performatywność” jako jedną z trzech „technologii politycznych” (policy technologies) reformy edukacyjnej; dwoma pozostałymi były „rynki” oraz „menadżeryzm”. Performatywność to:

technologia, kultura oraz sposób regulacji, obejmujące sądy, porównania oraz formy reprezentacji będące środkami zachęty, kontroli, zużycia i zmiany - oparta jest ona na nagrodach i sankcjach (zarówno materialnych, jak i symbolicznych). Wyniki (performances) (pojedynczych podmiotów lub organizacji) służą za miary produktywności oraz wydajności, czy też reprezentacje „jakości” lub „momenty” promocji albo kontroli. Jako takie przedstawiaja, zawieraja czy reprezentują cenę, jakość czy wartość jednostki lub organizacji w polu oceny. Kwestia tego, kto kontroluje pole oceny jest kluczowa (Ball 2003, 216).

Według Balla te urzeczowione technologie reformy sa ,niestabilne, nierówne, ale w oczywisty sposób niedające się zahamować”. Zostają „wcielone w »hipotetyczne światy« wielu akademickich dydaktyków”. Zmieniają to, co robimy oraz to, kim jesteśmy. Reforma ta stworzyła „zinstytucjonalizowaną schizofrenię”, charakteryzującą się „zdecentralizowanym otoczeniem”, zarządzanym poprzez „systemy monitoringu i wytwarzania informacji”. W tym „zaawansowanym liberalnym” środowisku, deregulacja jest procesem ponownej regulacji, oddawanie kontroli jest nowa formą kontroli, mniej widzialne państwo nadzoruje poprzez samoregulację nowych podmiotowości: „przedsiębiorczych podmiotów”, które „przeżywają egzystencję kalkulacji” i podejmuja „intensywna pracę nad soba”.

Ta „forma brzuchomówstwa” nadzorowana jest przez „systemy oceny, ustanawianie celów, porównania wydajności” itd., prowadząc do „taktyk poszukiwania bezpieczeństwa”, „egzystencjalnych lęków i strachu”. „Neoliberalny zawodowiec” wykonuje swoje obowiązki w obrębie i jako część regulacyjnego otoczenia, w którym „wartość zastępuje wartości”. Jest to „nieautentyczna”, „sprzeczna” egzystencja, która jest „ontologicznie niepewna”. „Cele

\footnotetext{
${ }^{2}$ Tytuł niniejszego podrozdziału w oryginale to „Performing academic labour” [przyp. tłum.].
} 
nauczyciela stają się sprzeczne, motywacje stają się niejasne, a samoocena niepewna". Schizofrenia instytucji prowadzi do „swego rodzaju schizofrenii wartości” mając „potencjał »pęknięcia« między nauczycielskim osądem dotyczącym »dobrych praktyk» a «potrzebami« ucznia i surowymi normami wykonania”. Prowadzi to do wywołania „poczucia winy, niepewności, niestabilności i wyłonienia się nowej podmiotowości”. Konsekwencją są również zmagania, które „często są uwewnętrzniane i wiążą się z przekładaniem troski o siebie ponad obowiązki względem innych”. „W wykonaniu (performance) nie ma miejsca na troskę [...], chodzi raczej o rzeczy, które robimy sami sobie i innym".

Ball podsumowuje swoje rozważania piszacc, że wskutek utowarowienia wiedza zostaje „uzewnętrzniona”, a w konsekwencji ulega „odspołecznieniu”. W wyniku tego nauczyciel zmaga się z efektami utowarowienia oraz walczy przeciwko nim, co samo w sobie „zakłada głębokie przesunięcie w istocie stosunku miedzy pracownikami a ich własną pracą". W rezultacie pojawia się owa „korozja charakteru”, jak również brak miejsca na autonomiczną czy kolektywną troskę.

Tym, co w swoim treściwym, polemicznym eseju przedstawia Ball, są moim zdaniem kapitalistyczne warunki zatrudnienia (work), stanowiące „formę żywej śmierci” (Dinerstein i Neary 2002,11). Uważam, że wartość jego artykułu stanowi elokwentny sposób rozszerzenia słownika, który w wielu rozmowach stosowałem do opisania własnej pracy: „schizofreniczna”, „intensywna praca nad soba”; „oddanie kontroli jako nowa forma kontroli”; „zjawisko kalkulacji”; „,cele nauczyciela stają się sprzeczne, motywacje stają się niejasne, a samoocena niepewna".

W artykule Balla kapitalistyczna praca została opisana i do pewnego stopnia zanalizowana tak, jak przejawia się ona na uniwersytetach, w koledżach i szkołach. Tym, co się jawi, jest w istocie wykonanie (performance), ale nie wystarcza to do wyjaśnienia, co dzieje się za kulisami i wprawia całe przedstawienie w ruch. Ball ma rację, gdy wskazuje na „epidemię” idei reformatorskich „głoszonych przez potężnych agentów w rodzaju Banku Światowego czy OECD”. Jednakże jego artykuł nie rozwija kwestii uznania performatywnej natury tych czynników. W czyim imieniu działają? Czego są agentami? Jaka jest ich rola w całej tej „grze”? W istocie, czym jest ich „gra w modernizacje”? Problem z artykułem Balla, pomimo jego całej opisowej i emocjonalnej mocy, polega na tym, że zawarta w nim analiza nie rozciaga się na omówienie kategorii ekonomicznych, które wprawiły te „niedające się powstrzymać” technologie w ruch, a ich ,sprawcy” zostają urzeczowieni w postaciach Banku Światowego i OECD, nie zaś ukazani jako „uosobienie kategorii ekonomicznych” (Marks 1968, 8). Artyku1 nie wskazuje, że sami kapitaliści mogą być uosobieniami kapitału oraz że „hipotetyczny świat” tego „nowego rodzaju podmiotów nauczycielskich” oraz ich podmiotowości jest światem podmiotowości wartości, „automatycznie działającego podmiotu” (Marks 1968, 178) oraz „samoczynnie napędzającej się substancji” (Marks 1968, 179) życia społecznego. Jeśli ten ruch 
rzeczywiście „wyraźnie nie daje się powstrzymać”, jak twierdzi Ball, musimy odsłonić „historycznie określoną logikę” (Postone 1993, 285) stojąca za tą „grą”, lub żyć w bezsilności wpajanej nam przez esej Balla: w formie żywej śmierci.

W całej swojej krytyce ekonomii politycznej Marks wielokrotnie odnosi się do języka performansu (spektaklu). Dowiadujemy się o „maskach”, „uosobieniach” oraz „dramatis personae", z których kluczowymi postaciami są kapitalista i robotnik, każdy odgrywający swoja rolę w „samopomnażaniu wartości kapitału” (Marx 1988, 84). Te odniesienia do performatywności nie są po prostu kwestią literackich ozdobników, ale odnoszą się do Marksowskiej metody krytyki, mającej na celu rozróżnienie między sposobami przejawiania się rzeczy w ich konkretnej formie, a ich rzeczywistą istotą jako abstrakcyjnych, społecznych kategorii panujących nad nami. Jak słusznie stwierdza Ball, edukacja stała się towarem, ale dzięki Marksowi wiemy, że towar jest formą fetyszu - historycznie określoną postacią bogactwa, która przejawia się w kapitalistycznym sposobie produkcji. Zatem by zrozumieć, w jaki sposób praca akademicka przejawia się jako towar, musimy opuścić „sferę cyrkulacji i wymiany towarów” i analizować „tajemniczą siedzibę produkcji” (Marks 1968, 203).

Ważnym punktem w tej argumentacji jest, jak uważam, to, że podczas gdy towar jest tym, co Marks nazywał „ekonomiczną formą komórkową” społeczeństwa kapitalistycznego, wychodząc od której można i należy analizować wszystko pozostałe (Marks 1968, 6), istnieje jeszcze pewien „szczególny” towar: „siła robocza”. Posiada on szczególny status ponieważ, jak twierdzi Marks, „jest źródłem wartości” (Marks 1968, 193), jedynym towarem, który może tworzyć nowa wartość dla kapitalisty. Po pierwsze, za pomoca wydłużania czasu wykonywania pracy, tj. przedłużania dnia roboczego - co posiada swoje naturalne ograniczenia. Po drugie, kompresując czas, tj. zwiększając produktywność pracy przez różne metody zmian jej wydajności. To właśnie, jak sądzę, jest kluczem do zrozumienia tego, co kryje się w obserwacjach Balla dotyczących narzuconej performatywności pracy akademickiej. W ramach naszej performatywności, dydaktycy wykonują i stopniowo wcielają to, co na koniec sprowadza się do kompulsywnego i bezwzględnego pragnienia kapitału do zwiększania „czasu pracy dodatkowej”, ponad „czas pracy niezbędnej”, co Marks określał technicznie jako „wyzysk”. Imperatyw kapitału do wyzyskiwania pracy, jego jedynego dynamicznego źródła wartości dodatkowej, znajduje się w samym sercu tego performansu i „schizofrenii” performatywności, która, w myśl opisu Balla, można rozumieć jako dotkliwy przejaw bezwzględnej potrzeby kapitału do subsumowania, zrównywania i waloryzowania wszystkich aspektów ludzkiego życia. Rozmyślając o „zgrozie” tego szaleństwa, praca w społeczeństwie kapitalistycznym może rozpoznać w sobie wyłącznie to, czym może być, to znaczy „paliwem dla żywego ognia” (Rikowski 2002). 


\section{Przechodzenie od abstrakcji do konkretu}

Jeśli spróbujemy wyszukać „marx*” we wszystkich 24 numerach (ponad 250 artykułów, recenzji i wywiadów) czasopisma Workplace: A journal for academic labour, znajdziemy 53 artykuły. Spośród nich zaledwie 14 formalnie cytuje prace Marksa, zaś pięć bezpośrednio odnosi się do jego prac na poziomie teoretycznym (Caffenzis 2008; Gulli 2009; Moten i Harney 1999; Pekkola 2013; Wexler 2008); zaledwie dwa zaś uważnie posługują się jego metoda (Caffenzis 2008; Moten i Harney 1999). Jak na czasopismo, które przede wszystkim skupione jest na pracy akademickiej (academic labour), oznacza to zapomnienie - być może nawet unikanie - własnej krytycznej podstawy teoretycznej.

Spośród wszystkich 24 numerów czasopisma, najbardziej złożone wykorzystanie zarówno Marksowskiej teorii społecznej, jak i metody znajdziemy w artykule Motena i Harneya. W tekście zatytułowanym „The Academic Speed-Up”, wskazuja oni na cztery możliwe podejścia do badania społeczeństw kapitalistycznych (1999, 24-25):

1. Istniała praktyczna wiedza biznesmenów odnośnie tego, w jaki sposób działa rynek, wiedza, która okazywała się prawdziwa, ponieważ zwiększała ich bogactwo.

2. Istniała wulgarna propaganda dziewiętnastowiecznych ekonomistów i polityków, którzy stworzyli teorię na bazie tej praktycznej wiedzy, by następnie jej bronić. Ich wiedza również była prawdziwa tylko w tym stopniu, do jakim byli w stanie zdominować społeczeństwo swoimi (według Marksa) prymitywnymi schematami praw rządzących rynkiem.

3. Istniały prace teoretyczne klasycznych ekonomistów politycznych w rodzaju Smitha czy Ricardo, których bardziej skomplikowane i pogłębione analizy ludzkiej kondycji wytworzonej przez rynek Marks podziwiał jako prawdziwszy obraz historycznego momentu kapitalizmu ukazany z rynkowego punktu widzenia.

4. Była również własna prawda Marksa, dotycząca tego, że kondycję ludzką pod władzą rynku można zrozumieć wyłącznie przez wyjście poza rynek, uhistorycznienie go i uzupełnienie obrazu o odbywający się zakulisowo proces produkcji, sprawiający, że rynek w ogóle jest możliwy.

Moten i Harney zwracają uwagę na to, że większość krytycznych analiz pracy akademickiej (włączyłbym w nie powyższy przykład Balla), rozpoznaje problem gdzieś między pierwszym a drugim poziomem analizy, to znaczy problemem są dla nich (1) warunki procesu pracy (np. prekarność czy wyrazy performatywności), lub (2) ideologie, które wspierają i podtrzymuja proces pracy, tj. neoliberalizm. 
Dlatego też jakikolwiek autor lub autorka opierający/a swoją argumentację na krytyce „neoliberalizmu” odsłania jednocześnie ograniczenia własnego wywodu. Jak stwierdził Moishe Postone, istnienie różnych historycznych konfiguracji kapitalizmu (np. liberalnego, fordystycznego, neoliberalnego) „wskazuje bardzo silnie na to, że najbardziej podstawowych cech kapitalizmu nie sposób całkowicie utożsamić z jakąkolwiek jego bardziej określona historyczną konfiguracja" (Postone 2005). Argument, który rozwija w licznych swoich pracach zasadza się na tym, że nasza krytyka musi opierać się na kategoriach w pełni adekwatnych względem naszego historycznego położenia, tj. kapitalizmu. Tradycyjna, znajdująca się pod wpływem marksizmu, krytyczna analiza rynku i podziału własności prywatnej udowodniła, że nie nadaje się na podstawę emancypacyjnej krytyki. Jej kategorie wyprowadzone zostały z perspektymy pracy i jej urzeczowienia, zamiast celować w jej zniesienie czy przekroczenie (Marksowskie pojęcie w tym kontekście to oczywiście Aufheben). To znaczy, praca, chociaż uznana za kluczową kategorię krytycznej teorii społecznej, nigdy sama nie została poddana negatywnej krytyce, w ten sam sposób, w jaki poddane jej zostały inne cechy kapitalistycznego życia społecznego.

W podobnym duchu Simon Clarke określił „neoliberalizm” jako „ponowne utwierdzenie fundamentalnych przekonań liberalnej ekonomii politycznej, które stanowiły dominująca ideologię polityczną w XIX wieku" (Clarke 2004, 57). Jak wskazuje, pomimo różnorodności okresowych przejawów kapitału, przeszkodą jest to, że nasza krytyka musi zawsze być gotowa podjać problem „kapitału”, jako fundamentalnej i historycznej kategorii. Jeśli domniemany problem stanowi „neoliberalizm”, wszelkie próby krytykowania go najpewniej pozostaną tak powierzchowne, nienaukowe i moralistyczne, jak sama neoliberalna teologia. Krótki artykuł Clarke’a o neoliberalizmie można odczytać jako próbę przemieszczenia obiektu krytyki poza ten względnie powierzchowny poziom analizy, na bardziej podstawowe rozumienie problemu (który można dopasować do trzeciego punktu wskazanego przez Motena i Harneya), a następnie jego rewolucyjnej, naukowej krytyki (punkt czwarty). Podobnie Moten i Harney twierdzą że „na nasze barki spada wówczas przede wszystkim obowiązek unikania tego, by nasza rozmowa o kryzysie nie stała się wulgarną wiedzą dotycząca samych tych warunków. Powinniśmy unikać brania tej wiedzy praktycznej i przekładania jej bezpośrednio na teorię warunków. Zamiast tego, powinniśmy podjać dalsze kroki na drodze badania dostępnej nam, ukonstytuowanej teorii warunków" (Moten i Harney 1999, 25).

Część ich artykułu, do której się tu odnoszę, została zatytułowana „Abstrahowanie pracy akademickiej" i jak sądzę powinniśmy traktować to jako odniesienie do metody stosowanej przez Marksa, to znaczy do „wznoszenia się od abstrakcji do konkretu” (Marks 1986, 53). Uważam, że kwestią kluczowa jest zrozumienie, co to właściwie za soba pociąga.

Gdy Marks w swoim dziele pisze o pracy, odnosi się do pracy kapitalistycznej; to znaczy, do pojęcia pracy w kontekście historycznym, w którym kapitalistyczny sposób 
produkcji został upowszechniony w całym społeczeństwie. Jego analiza pracy ma na celu naukowe przedstawienie sposobu, w jaki praca w warunkach kapitalistycznych różni się od pracy $\mathrm{w}$ okresie poprzedzającym kapitalizm oraz w społeczeństwach niekapitalistycznych. W ten sposób, praca kapitalistyczna jest zarówno bezpośrednio, jak i pośrednio przeciwstawiana przeszłej historycznej formie pracy, jak i przyszłej możliwej jej postaci. W swoich wczesnych dziełach, jak choćby pisanej wspólnie z Engelsem Ideologii niemieckiej (Marks i Engels 1961), Marks przemyślał dogłębnie i rozlegle swoje podejście krytyczne, uznając je za jednoznacznie dialektyczne, historyczne i materialistyczne. W praktyce oznacza to, że tym, czego poszukiwał, było odsłonięcie sprzeczności i antagonizmów między rzeczami (tj. ideami, praktykami, podmiotowościami, strukturami społecznymi), które możemy określić na podstawie zarejestrowanej historii i obserwacji poczynionych odnośnie danego społeczeństwa. Marks podkreśla, że ludzie oraz sposób, w jaki wchodzą oni ze sobą nawzajem $\mathrm{w}$ interakcje, sa wynikiem oddziaływania rzeczywistych, społecznych i historycznych sił wytwórczych. Na sposób, w jaki myślimy wpływają nasze działania oraz działania wszystkich innych osób na świecie, zapośredniczone w historii i społeczeństwie. Bardziej niż przez jakąkolwiek zewnętrzną instancję w rodzaju Boga, jesteśmy określeni naszym własnym stworzeniem: tworzymy sami siebie w procesie tworzenia historii. Marksowski pogląd na historię zakłada, że istnieją tendencje, które na pierwszy rzut oka sprowadzają się do praw, ale w rzeczywistości są przygodne względem ludzkiego działania, a zatem nie moga być wykorzystywane do uzasadniania status quo. Wszystko zawsze znajduje się w ruchu i jest otwarte na krytykę.

Marks uważał swoją metodę za racjonalną, naukową i współdzieląca cechy metodologiczne z naukami ścisłymi. W swoim badaniu stosował różne techniki, jak choćby szczegółowe obserwacje, logikę, odniesienia do literatury czy wykorzystanie różnego rodzaju dokumentów (np. angielskich „Niebieskich ksiag”) do wyjaśnienia społecznych „praw" i tendencji. W poszukiwaniu konkretnych cech naszego codziennego życia zidentyfikował świat ræeczyywistej abstrakciji (Sohn-Rethel 1978; Jappe 2013), który często znajduje się w wyraźnym kontraście względem tego, co jawi się jako rzeczywiste i naturalne. Dzięki temu jego analizy są jednocześnie w sposób systematyczny abstrakcyjne i konkretne. Uznaje materialną rzeczywistość naszego życia oraz świat, w którym żyjemy, ale wyraża sceptycyzm względem zjawisk znajdujących się na powierzchni, a szczególnie zdroworozsądkowych idei, które bierzemy za pewnik i w których widzimy w nich coś transhistorycznego czy naturalnego, jak choćby idea „pracy”.

W przedmowie do Kapitatu porównuje stojące przed sobą zadanie do tych wykonywanych przez fizyków, biologów czy chemików, wyjaśniając, że w badaniu społeczeństwa „siła abstrakcji” musi zająć miejsce mikroskopu i odczynników chemicznych (Marks 1968, 6). Chociaż omawiając szczegółowo kapitał wykorzystuje przykłady określonych 
rodzajów pracy, takich jak praca krawców, tkaczek, rolników czy pracowników fabrycznych, abstrahuje w ten sposób do czegoś w rodzaju „idealnego przekroju” (Marks 1982, 577), by w ten sposób zaproponować „analizę kapitału w jego rdzennej strukturze” (Marks 1984, 405). Jako taka, jego analiza pracy miała posłużyć do badania wszelkich form pracy występujących w kapitalistycznym sposobie produkcji, tym samym oferując systematyczne, dogłębne i wielowymiarowe narzędzie, jak również nową koncepcję pracy w jej czasowych, historycznych i zdenaturalizowanych formach.

W Zarysie krytyki ekonomii politycznej (1986) Marks określił swoje podejście krytyczne jako „,metod[e] wznoszenia się od abstrakcji do konkretu” (Marks 1986, 53), dalej Marks rozwija wyjaśnianie tego, co rozumie przez tę metodę, odnosząc się do pojęcia „ludności”:

\begin{abstract}
Wydaje się, że słusznie jest zacząć od tego, co realne i konkretne, od rzeczywistej przesłanki, a więc, na przykład, w ekonomii politycznej od ludności, stanowiącej podstawę i podmiot całego społecznego aktu produkcji. Tymczasem przy bliższym rozważeniu okazuje się, że jest to fałszywe. Ludność jest abstrakcja, jeśli pominę na przykład klasy, na które się ona dzieli. Z kolei klasy są czczym słowem, jeżeli nie znam elementów, na których się one opieraja. Na przykład praca najemna, kapitał itd. Te zaś zakładają istnienie wymiany, podziału pracy, cen itd. Kapitał, na przykład, jest niczym bez pracy najemnej, bez wartości, pieniądza, ceny itd. Gdybym więc zaczął od ludności, przedstawiłbym całość w sposób chaotyczny, dopiero drogą bliższego określania doszedłbym analitycznie do prostszych pojęć; od przedstawionego konkretu do coraz cieńszych abstrakcji, aż dotarłbym do najprostszych określeń. Stąd musiałbym rozpocząć podróż powrotna, aż wreszcie dotarłbym znowu do ludności, tym razem jednak nie do chaotycznie przedstawionej całości, lecz do bogatego całokształtu wielu określeń i stosunków (Marks 1986, 52).
\end{abstract}

Natomiast zaraz po tym fragmencie, rozjaśnia relację między tym, co abstrakcyjne a tym, co konkretne:

To, co konkretne, jest konkretne ponieważ jest zestawem wielu określeń, a wiec jest jednością różnorodności. W myśleniu występuje one przeto jako proces zestawiania, jako wynik, nie zaś jako punkt wyjścia, chociaż jest rzeczywistym punktem wyjścia, a zatem również punktem wyjścia oglądu i wyobrażenia. [...] abstrakcyjne określenia prowadzą do odtworzenia tego, co konkretne w drodze myślenia (Marks 1986, 52-53).

W tym tekście Marks zdecydowanie odróżnia swoje podejście od Heglowskiego idealizmu, twierdząc, że jego własne dialektyczne wykorzystanie abstrakcji opiera się na i jest zakorzenione w konkretnych, materialnych i społecznych cechach życia ludzkiego. Te rzeczywiste abstrakcje posiadają określoną moc, ponieważ reprodukuja to, co konkretne, będące koncentrowanym wynikiem rzeczywistych abstrakcji (Iljenkow 1982, 32-34). Podaje przykład abstrakcji „,wartości wymiennej”, która może istnieć wyłącznie w dialektycznym stosunku z konkretnymi stosunkami społecznymi w danym społeczeństwie, takimi jak rodzina, wspólnota czy państwo. 
W dalszej części omawia sposób, w jaki abstrakcja może ulec zmianie w odniesieniu do konkretnego świata. Może się wydawać, że proste abstrakcje zakładają bardziej złożoną rzeczywistość, ale w istocie, jak twierdzi, wyrażają historyczny rozwój społecznych warunków i stosunków w danych czasach i miejscach. Marks stwierdza zatem, że „bieg abstrakcyjnego myślenia, wznoszącego się od najprostszego do złożonego, odpowiadałby rzeczywistemu procesowi historycznemu" (Marks 1986, 54). W rezultacie jest to ostrzeżenie przed metodologicznym posługiwaniem się takimi pojęciami jak „,pieniądz”, „wymiana”, czy „praca” itd. do wszystkich ludzi, we wszystkich czasach i miejscach. Jest to argument na rzecz ujęcia przygodnej podstawy pojęć teoretycznych, zanim zostaną zastosowane do konkretnego świata (Marks 1986, 56). Stosowanie istniejących kategorii do wszystkich momentów w historii nie jest wyłącznie błędem, ale również skęepowaniem, ponieważ ogranicza naszą zdolność do rozumienia zarówno teraźniejszości, jak i przeszłości. Marks twierdzi, że kategorie takie, jak „pieniądz” oraz „praca” wyrażaja zarówno „to co jest dane zarówno w rzeczywistości, jak i w głowie” a zatem są „formą pewnego bytu egzystencjalnego”, ale widzianą ze specyficznego, ograniczonego punktu widzenia (Marks 1986, 57). W ten sposób, przecząc wszelkim pozytywistycznym zakusom, Marks twierdzi, że błędne jest myślenie, iż społeczeństwo „nawet pod waględem naukowym, zaczyna się dopiero wtedy, gdy o nim, jako takim, właśnie mowa” (Marks 1986, 57).

Punktem wyjścia Marksowskiej analizy jest dominujący, panujący sposób produkcji we współczesnym społeczeństwie, to jest „kapitał”, bardziej niż to, co jak twierdzi, stanowi powiązane, ale drugorzędne kategorie w rodzaju „ludności” czy „własności ziemskiej” (Marks 1986, 57). Chociaż może wydawać się „logiczne”, by rozpocząć od konkretnego miejsca zainteresowania (np. „ludności”, ,,szkolnictwa wyższego”, „nauki”, „pracy akademickiej”, itd.) i następnie rozwijać swoje analizy właśnie z tego miejsca, Marks twierdzi, że sposób produkcji (to jest kapitał) dominuje - „panuje” - nad ciałem i umysłem do takiego stopnia, że bez rozpoczynania od zbadania fundamentalnych dla kapitalizmu kategorii (a zatem również własnych abstrakcji) będziemy w naszym podejściu do analiz (np. pracy akademickiej) poruszać się mniej więcej na ślepo. W efekcie twierdzi, że powstajemy z kapitału - jesteśmy kapitałem i musimy rozpocząć naszą analizę od właściwego zrozumienia tego, co oznacza bycie człowiekiem.

W końcowym fragmencie tej części Wprowadzenia Marks zwięźle prezentuje swoja metodę „wznoszenia się od abstraktu do konkretu” przy wykorzystaniu przykładu „,bogactwa narodu" (zob. Rosdolsky 1977, 27). Wyjaśniając, w jaki sposób pojęcie to weszło do użytku i z czasem przekształciło się w bezkrytyczne uzasadnienie koncepcji nowoczesnego państwa, Marks zarysowuje to szczególne podejście metodologiczne (Marks 1986, 58). Jeśli mielibyśmy zastosować je do analizy pracy akademickiej, wówczas (i) musielibyśmy rozpoczać od ogólnych kategorii, które pozornie mają zastosowanie dla wszystkich ludzi, we wszystkich epokach, na 
przykład „pracy”; (ii) następnie przeszlibyśmy do zbadania współczesnych form tych kategorii, na przykład „kapitału”, „pracy najemnej”; (iii) kolejno zbadalibyśmy wzajemne stosunki zachodzące między abstrakcyjnym charakterem tych kategorii $\mathrm{w}$ ich skoncentrowanych, konkretnych formach społecznych, na przykład „miejscu pracy”, „państwie”; (iv) później przeanalizowalibyśmy dialektykę między tym, co konkretne a tym, co abstrakcyjne rozwiniętą dotychczas do postaci bardziej rozległej, to jest obejmującej np. globalny rynek pracy; (v) by wreszcie zbadać dialektykę rozwiniętą na poziomie systemowym, na przykład w kontekście wzajemnych stosunków między globalną produkcją, wymianą, bezrobociem, kryzysami itd. Rozpoczęliśmy zatem od wydawałoby się prostej kategorii „pracy” i przemieściliśmy się dialektycznie, by umiejscowić ją czasowo, zarówno w kategoriach jej abstrakcyjnego charakteru, jak i jej przejawów na lokalnym, społecznym poziomie, oraz jej roli w międzynarodowej polityce, rynkach czy wojnie itd. Pojmowanie „pracy” czy jakiejkolwiek innej prostej kategorii w dowolny inny sposób jest przejawem braku rozumienia jej.

Jak podsumowałem to już w pierwszej części niniejszego tekstu, dwoisty charakter towarów w społeczeństwach kapitalistycznych wyraża dwoisty charakter ludzkiej pracy wykonywanej w ich ramach. Wartość użytkowa czy użyteczność towaru wyraża konkretny, fizjologiczny, użyteczny aspekt pracy, a wartość wymienna i wartość towarów wyraża abstrakcyjny, społeczny i homogeniczny aspekt pracy. W pierwszym rozdziale Kapitału Marks wprowadza swoje kluczowe kategorie teoretyczne, w których odsłania się jego naukowy projekt krytyki ekonomii politycznej: forma towarowa (wartość użytkowa oraz wartość wymienna); odpowiadający jej dwoisty charakter pracy (praca konkretna i abstrakcyjna); forma wartości (względna i ekwiwalentna forma, z której wynika forma pieniężna) oraz miara wartości (społecznie niezbędny czas pracy). Kluczowa (choć zaniedbana) kategoria stworzona przez Marksa jest „praca abstrakcyjna” (Bonefeld 2010). Praca abstrakcyjna to „substancją wartości”, ludzka siła robocza „,wydatkowaną bez względu na formę jej wydatkowania” (Marks 1968, 43). Jest czymś „zastygłym”, „zakrzepłym”, redukcją do „określonej ilości równej, ogólnej, niezróżnicowanej, społecznej, pracy abstrakcyjnej” (Marks 1988, 71); czy też „po prostu praca, pracą abstrakcyjną, absolutnie obojętną na swe poszczególne określenia” (Marks 1986, 215)

\footnotetext{
Surdut o tyle tylko posiada wartość, że jest wyrazem, przyjmującym formę rzeczy, ludzkiej siły roboczej wydatkowanej w produkcji, a zatem tak długo, jak jest skrzepem abstrakcyjnie ludzkiej pracy - pracy abstrakcyjnej, ponieważ abstrakcja wytworzona została z określonego, użytecznego konkretnego charakteru zawartej w nim pracy, ludzkiej pracy, ponieważ praca liczy się tutaj wyłącznie jako wydatkowanie ludzkiej siły roboczej jako takiej (Marks 1978, 136).
}

W tym jednym zdaniu analitycznym Marks rozpoczyna od tego, co abstrakcyjne (wartości) by dotrzeć do tego, co konkretne (pracy). W praktyce jednak nie jest to oczywiście jednokierunkowy proces. Podobnie jak względne i ekwiwalentne formy wartości w ramach 
stosunków wymiany, wszystkie towary (to jest dobra i usługi, w tym edukacja wyższa) reprezentuja „ludzką pracę w abstrakcyjnej postaci” służąc za ekwiwalent dla pracy abstrakcyjnej wyrażanej w innym towarze. Zarazem jednak towar jest również produktem „określonej, użytecznej, pracy konkretnej”, w ten sposób, że „praca konkretna staje się forma przejawiania się swego przeciwieństwa, abstrakcyjnie ludzkiej pracy” (Marks 1968, 67).

„Praca abstrakcyjna” nie jest wobec tego substancją w sensie jakiegoś jądra czy istoty rzeczy; jest kategorią teoretyczną wyrażającą rzeczywisty, aktywny proces społeczny, który sam zazwyczaj pozostaje niewyrażony, dzięki czemu pozwala nam na lepsze zrozumienie kapitału.

\section{Od bycia do działania}

Niebezpieczeństwo rozpoczynania analizy od konkretnych warunków pracy akademickiej, jak wskazują Postone, Clarke, czy Moten i Harney, polega na tym, że jeśli ograniczymy się do zwracania uwagi tylko na te warunki, w których odbywa się proces pracy oraz ich ideologiczne odpowiedniki, wówczas prawdopodobnie będziemy tworzyć politykę odpowiadająca na „wulgarną" propagandę „,neoliberalizmu” oraz jej aparaty, nie zaś zakorzenioną w fundamentalnej, immanentnej krytyce „odbywającego się na zapleczu procesu produkcji”; czyli tego, co w rozdziale o „Kupnie i sprzedaży siły roboczej” Marks określa jako „tajemnicza siedzibę produkcji”.

Opuszczamy więc wraz z posiadaczem pieniędzy i posiadaczem siły roboczej tę sferę pełna gwaru, gdzie wszystko dzieje się na powierzchni i na oczach wszystkich, aby udać się za nimi do tajemniczej siedziby produkcji, na której progu widnieje napis: No admittance except on business [Wstęp tylko dla interesantów]. Tu dowiemy się nie tylko, jak kapitał wytwarza, ale także jak się wytwarza sam kapitał. Tu musi się wreszcie odsłonić tajemnica robienia zysku (Marks 1968, 203).

Moten i Harney ponownie wyrażają tę ideę w kontekście szkolnictwa wyższego:

Z dala od sfery publicznej, w której rządzą idee szkolnictwa wyższego, gospodarczej ekspansji i kurczenia się, obywatelstwa, możliwy staje się inny sposób interpretowania tych warunków. Warunki, o których mowa, są mroczniejsze, zarówno dlatego, że pozostają ukryte przed jasnym światem sfery publicznej, jak również dlatego, że składaja się na nie potężne siły w rodzaju uprzemysłowienia, centralnego planowania, proletaryzacji czy walk przeciwko stosunkom kapitalistycznym. Można powiedzieć, że jest to inny sposób rozumienia tego złotego wieku, który nie jest aż tak złoty, ale może być to sposób na zbudowanie lepszej teorii tych warunków pracy (Moten i Harney 1999, 25). 
Moten i Harney w swoim artykule wielokrotnie dokonują rozróżnienia między indywidualną a społeczną produkcją. Rozróżnienie między praca jednostkową a społeczną, kooperatywną w obrębie akademii leży u podłoża problemu pracy kapitalistycznej, ponieważ to w ramach podziału i uspołecznienia pracy zostajemy wyalienowani od tego, co wytwarzamy, jak również od siebie nawzajem. Społeczne stosunki zostaja przekształcone w stosunki własności prywatnej. Moten i Harney rozwijają krytykę „marzeń” o „intelektualnym rzemiośle” oraz „złotym wieku”, który rzemiosło to przedstawia, omawiając je jako sposób produkcji, w którym jednostka przynosi swoje towary na rynek, ,gdzie student czy opinia publiczna moga dostrzec bezpośrednio wartość jego pracy, gdzie autor stoi obok własnego dzieła”. W odróżnieniu od tego ujęcia naukowca, Moten i Harney skupiają się na ržeçywistej praktyce pracy akademickiej w społeczeństwie kapitalistycznym, jako na „społecznym świecie tworzenia i współdzielenia wiedzy”, gdzie zarówno naukowcy, jak i studenci kooperują w „produkcji, cyrkulacji i realizacji” towarów opartych na wiedzy (Moten i Harney 1999, 26).

Moten i Harney pozostają krytyczni względem „wulgarnej” konceptualizacji pracy akademickiej, w ramach której uniwersytet postrzega się jako rynek, jak również względem romantycznego jego postrzegania, gdzie jest „szczególnym i ograniczonym braterstwem” jednostek oferujących swoje wyroby, czy tej wizji, w której przedstawiany jest jako centralnie planowana fabryka, wytwarzająca i wprowadzająca do sfery cyrkulacji wiedzę w postaci towarów w celu realizacji wartości wymiennej (Tancred-Sherrif 1985). Obie perspektywy rynkowe, jak twierdza, zdradzają uwewnętrznienie linii produkcyjnej „od złotego wieku, w którym nie chcieliśmy dostrzec, że jesteśmy częścią centralnie planowanej fabryki wiedzy, aż po to, co moglibyśmy nazwać uwewnętrznieniem produkcji cybernetycznej" (Moten i Harney 1999, 28).

W powiązanym z tymi wywodami rozdziale zatytułowanym „Doing Academic Work” (Harney i Moten 1998) autorzy powtarzają swój argument mówiący, że naukowcy wyrażają się krytycznie o warunkach własnej pracy, jednak dystansuja się również od większości pracowników, nie uznając zarówno „wzajemnej współzależności oraz społecznego charakteru swoich własnych wytworów”. Ich stanowisko można by sprowadzić do stwierdzenia, że „większość profesorów w Stanach Zjednoczonych jest częścią proletariatu sektora usługowego tego kraju” (Harney i Moten 1998, 155). Mówiąc w skrócie, sugerują, że na podmiotowość naukowców zdaje się składać postrzeganie akademickich warunków pracy (work), jako czegoś powiązanego z określonym stanowiskiem raczej niż z wykonywaniem konkretnych cżynności. Prowadzi to autorów do położenia nacisku nie na to, co nazywają byciem pracownikiem akademickim, ale na to, co oznacza wykonywanie pracy akademickiej (labour).

Wywód Harneya i Motena wskazuje możliwy powód tego, że większość krytyk pracy akademickiej zatrzymuje się na poziomie fetyszu procesu pracy, to znaczy w obrębie dyskursu teorii wulgarnej, skupiając się na drobnych szczegółach naszych warunków pracy, zamiast na 
określonych, abstrakcyjnych siłach. Dzieje się tak z powodu braku wśród naukowców kolektywnego sprawstwa, zakorzenionego we wspólnym procesie produkcji uniwersytetu, jako społecznego, kooperatywnego przedsięwzięcia. W ten sposób właśnie pozostajemy zaprzątnięci naszymi indywidualnymi pozycjami na „rynku idei” (Marksowskiej sferze cyrkulacji), zamiast sposobem, w który reprodukujemy nas samych poprzez aktywną zależność od innych pracowników i studentów.

Nacisk na społeczny, kooperacyjny charakter pracy na uniwersytecie/fabryce nie jest stwierdzeniem, że w jakiś sposób sprzeciwia się ona kapitalistycznemu sposobowi produkcji, ale raczej, że go egzemplifikuje. Przywołajmy Marksowski rozdział o kooperacji, gdzie mówi on wyraźnie:

\footnotetext{
Forma pracy wielu jednostek, które pracują planowo obok siebie i razem ze sobą w tym samym procesie produkcji lub w różnych, lecz powiązanych procesach produkcji, nosi nazwę kooperacji. [...] Kooperacja pozostaje podstawową formą kapitalistycznego sposobu produkcji (Marks 1968, 383, 396).
}

By to uwypuklić, Harney i Moten bazują na stosowanym przez Michaela Burawoya pojęciu „społecznych stosunków w produkcji” zamiast na pojęciu „społecznych stosunków produkcji”. Szczególnie interesujące w ich argumentacji jest wskazanie, że społeczna praca nie opiera się wyłącznie na naukowcach, ale raczej na współpracujących akademikach i studentach. Przekonująco argumentują na rzecz tego, że naukowcy stale „odsuwają od siebie” zakorzenione „zagrożenie” tym, że siła robocza studentów jest ostatecznie ekwiwalentna ich własnej w ramach produkcji wiedzy, a opór ten jest stawiany przez stabilizowanie momentów cyrkulacji i realizacji jako „kategorii jednostkowości” (Harney i Moten 1998, 174). Utrzymywanie jednostkowej tożsamości naukowca sprowadza się do próby potwierdzania swojej godności. Rozszerzenie analizy pracy akademickiej jedynie na obszar warunków tak rozumianej pracy jest zrozumiałym wynikiem próby zachowania odrobiny godności w obrębie nieludzkiego procesu rzeczywistej abstrakcji.

W ten sposób naukowcy określają studentów jako konsumentów w ramach stosunku wymiany. W efekcie mamy tu do czynienia z aktem „hipostazowania tego, co konkretne”, w którym naukowcy izolują swoja pracę i fetyszyzują ją w postaci intelektualnego rzemiosła, a wreszcie oddzielają studenta jako indywidualnego konsumenta akademickiego produktu wiedzy. Umieszczanie studenta-pracownika z powrotem w roli studenta jest próbą stworzenia „dystansu i różnicy” między dwoma jednostkami (Harney i Moten 1998, 174), podczas gdy $\mathrm{w}$ istocie na kapitalistycznym uniwersytecie zarówno naukowcy, jak i studenci są względnymi i ekwiwalentnymi formami towaru siły roboczej połaczonymi w celu wymiany, a każdy z nich posiada zarówno konkretny, jak i abstrakcyjny charakter. Harney i Moten omawiają to wszystko wykorzystując przykład akcji afirmacyjnej, jednak uważam, że tym, co pośrednio staraja się 
ukazać jest fakt, że można odkryć Marksowską teorię „formy wartości” również w samym sercu stosunku kształcenia i uczenia się, między naukowcami i studentami (Marks 1968, 54-80; 1978). W tym stosunku „produkcyjnej konsumpcji” (Postone 1993, 383), towar siły roboczej zarówno nauczycieli, jak i studentów istnieje na „obu biegunach wyrazu wartości” (Marks 1968, 55), każdym względnym i ekwiwalentnym wobec drugiego w momencie wymiany. Stosunek wymiany jako taki jest również stosunkiem produkcyjnym, gdzie produkcja jest „bezpośrednio” konsumpcją (Marks 1986, 42). Jeśli zdefiniujemy kształcenie i uczenie się jako wydatkowanie siły roboczej studentów i nauczycieli w procesie produkcji towaru opartego na wiedzy, wówczas zaczniemy dostrzegać, że stosunek wymiany zachodzący między studentem a nauczycielem, gdzie każdy konsumuje siłę roboczą drugiego, jest również stosunkiem produkcyjnym, a nie wyłącznie takim, w którym wiedza zostaje dystrybuowana do konsumentów na rynku szkolnictwa wyższego (Neary i Winn 2009).

\title{
Wnioski
}

\begin{abstract}
Kwestią centralną dla Marksowskiej koncepcji przekroczenia kapitalizmu jest jego pojęcie ludzkiego, ponownego zawłaszczenia społecznie ogólnej wiedzy oraz zdolności, które zostały historycznie ukonstytuowane jako kapitał. Widzieliśmy, że według Marksa taka wiedza i zdolności, jako kapitał, dominują nad ludźmi; tego rodzaju ponowne przyswojenie pociaga za sobą przekroczenie sposobu dominacji charakteryzującego społeczeństwo kapitalistyczne, które ostatecznie zakorzenione jest w historycznie specyficznej roli pracy, jako czynności społecznie zapośredniczającej. W związku z tym u rdzenia jego wizji społeczeństwa postkapitalistycznego leży historycznie wygenerowana możliwość, że ludzie mogą objąć kontrolę nad tym, co tworzą, zamiast być tej kontroli poddani (Postone 1993, 373).
\end{abstract}

Pośród krytyków obecnego kryzysu w szkolnictwie wyższym występuje zrozumiała tendencja polegająca na chęci przywrócenia uniwersytetowi niegdysiejszej postaci, obrony uniwersytetu przed przekształceniem go w coś innego, do oporu wobec realnej subsumcji pracy akademickiej pod kapitał. Wydaje mi się, że opiera się ona na niezrozumieniu uniwersytetu jako środka produkcji oraz jego historycznej roli.

W ciagu całego dwudziestego stulecia mieliśmy do czynienia ze stopniowym procesem przekształcania nieprodukcyjnej pracy akademickiej w prace produkcyjna przez wcielanie jej w procesy pomnażania wartości (zob. Cleaver 2012; Harvie 2006; Neary 2012; Winn 2013). Nie powinno wobec tego dziwić nas, że eksperymenty z neoliberalizmem doprowadziły do urynkowienia szkolnictwa wyższego, ani że wysiłki ukierunkowane na odparcie tego procesu pozostaja w dużej mierze bezowocne. Powinniśmy uznać, że starania mające na celu powstrzymanie wprzęgania szkolnictwa wyższego w procesy pomnażania wartości, jak również 
przywrócenie go do wcześniejszej konfiguracji - gdy nie był powszechnie traktowany jako napęd wzrostu - są błędne.

Każdy projekt emancypacyjny krytycznie podchodzący do uniwersytetu jako środka produkcji wprzęgniętego $\mathrm{w}$ proces pomnażania kapitału musi w pierwszym rzędzie koncentrować się na ponownym przyswojeniu środków produkcji wiedzy poprzez ukierunkowanie wysiłków na przejęcie kontroli nad substancją wartości: procesem pracy. Wymaga to, jak uważam, nowych modeli demokratycznego szkolnictwa wyższego zorganizowanego bezpośrednio za pomoca kooperacji akademickiej i studenckiej siły roboczej; modeli praktyk, mających na celu ponowne odzyskanie ,intelektu powszechnego” (Marks 1986, 574) i uznających ,istnienie rosnącej przepaści między rodzajami pracy, które ludzie wykonują w społeczeństwie zapośredniczonym przez pracę, a rodzajem pracy, którą mogliby wykonywać, gdyby nie ta »konieczność« na gruncie kapitalizmu” (Postone 1993, 370). Wysiłek ten musi zostać zakorzeniony w bezkompromisowej krytyce ekonomii politycznej szkolnictwa wyższego, wychodzącej od jego najprostszych, immanentnych kategorii. Uznałaby ona i rozwinęła istotne efektywne zdolności naszych istniejących warunków historycznych w sposób, za pomocą którego wiedza czy „,masowa intelektualność” (Dyer-Witheford 1999, 488) postrzegana byłaby jako projekt emancypacyjny raczej niż zasób dla procesu pomnażania wartości.

W swoim artykule zatytułowanym „History and Helplessness, Mass Mobilization and Contemporary Forms of Anticapitalism”, Moishe Postone (2006) omawia pojęcie oporu w świetle historycznego rozwoju kapitalizmu. Uznaje je za wyraz "głęboko dualistycznego poglądu na świat, który zdaje się reifikować zarówno system dominacji, jak i ideę sprawstwa" (Postone 2006, 108). Dla Postone’a „opór” jest „antydialektyczną kategoria, niezdolną uchwycić swoich własnych warunków możliwości” (2006, 108). Jego argumentacja zakłada, że sprawstwo pracy akademickiej nie powinno być mierzone skalą tego, jak jesteśmy w stanie opierać się czy znosić system dominacji; zamiast tego immanentne, dialektyczne podejście rozpoznałoby, że postkapitalistyczny uniwersytet rozwinąłby się z warunków możliwości stworzonych przez uniwersytet kapitalistyczny. Innymi słowy, ,antykapitalistyczne” podejście chybia zarówno celu własnego oporu, jak i jego przedmiotu. Tym, co należy zrealizować jest zniesienie kapitalistycznego sposobu pomnażania wartości (Postone 2012, 30).

Rozwijana przez Postone'a analiza kapitalizmu, oparta na jego ponownej lekturze Marksa, wydaje się użyteczna z wielu powodów. Ukazuje on, że sposób kapitał jest historycznym sposobem produkcji, nadającym strukturę wszystkim obszarom życia społecznego; że jest dynamiczny i heteronomiczny. Jako „logika” wszystkich obszarów życia społecznego, kapitał jest określony, ale też przejawia się jako historyczna konieczność. Jako taki, kapitał wytwarza w nas i pośród nas poczucie bezsilności oraz tego, że przygodność sprowadza się do procesów reformy i powolnej poprawy zachodzących w ograniczeniach 
narzuconych przez kapitał. Osiagnięcia socjaldemokracji, na przykład, wskazują nam stopień historycznej nieokreśloności i możliwość wolności, chociaż nieustannie pojawiają się w obrębie ograniczeń narzuconych przez kapitał. Dla Postone’a rzeczywista historyczna nieokreśloność (to jest, wolność) może zostać zrealizowana jedynie w postkapitalistycznej społecznej formie życia. Immanentna, dialektyczna krytyka kapitału jako formy stosunków społecznych (a nie jako materialnej rzeczy, jak stereotypowo się go rozumie), odsłania przed nami że to, co jawi się jako abstrakcyjne, tajemnicze i rządzące całością, jest w istocie sprzeczne, oraz że to właśnie wewnętrzne napięcia tej „logiki” oferują nam historyczną podstawę dla przekroczenia kapitalizmu. Możliwość zniesienia kapitalizmu leży w obrębie samych sprzeczności kapitalizmu, to jest w obrębie formy towarowej. Wysiłki antykapitalistyczne w sposób typowy fetyszyzuja abstrakcyjną logikę kapitału, usiłując dostrzec coś,, czemu można się przeciwstawić, np. amerykańską hegemonię, państwo, bankierów. Postone uznaje ten zwrot od abstrakcji do konkretu za „wyraz głębokiej i fundamentalnej bezradności, zarówno konceptualnej, jak i politycznej" (Postone 2006, 102).

Jeśli przyjmiemy tego rodzaju perspektywę, nasze ujęcie sposobu produkcji wiedzy w szkolnictwie wyższym oraz jego pojmowanej roli i celu w życiu publicznym w ostatnim stuleciu musi wyjść od kategorialnego rozumienia kapitalizmu w jego historycznym sposobie produkcji, który reprodukuje uniwersytet. Ten krytyczny, intelektualny wysiłek musi zostać powiązany z praktycznymi staraniami uzyskania kontroli nad środkami produkcji wiedzy tak, żeby poprzez praxis zakwestionować istniejącą społeczną formę bogactwa, która zapośrednicza nasze życie w tej katastroficznej trajektorii. W ten sposób charakter i cel pracy akademickiej nieuchronnie się zmieni, a nasze istniejące warunki pracy staną się nieaktualne. Stosunek między nauczycielem a studentem może być wobec tego stosunkiem bezpośredniego uznania (obfitości) raczej niż zapośredniczonym przez ekwiwalent wartości (rzadkości). Dzięki nowej pedagogice nadmiaru (Neary i Hagyard 2010), „praca akademicka” taka, jak ja obecnie rozumiemy i przeżywamy, zostałaby zniesiona, a jej warunki przekroczone. Dałoby to początek nowym instytucjonalnym formom zaspokajania ludzkich potrzeb, które wciąż czekają na zaprojektowanie.

Przetoziyt Krystian Szadkowski 


\section{Wykaz literatury}

Barcan, Ruth. 2013. Academic Life and Labour in the New University. Farnham: Ashgate Publishing.

Ball, Stephen. 2003. „The teacher's soul and the terrors of performativity.” Journal of Education Policy 18(2): 215-228.

Bérubé, Michael. 2013. 'Among the majority'. Modern Language Association. 'From the President', retrieved on 2nd June 2014 from http:/ / www.mla.org/blog?topic $=146$

Bonefeld, Werner. 2010. „Abstract Labour. Against its nature and on its time.” Capital and Class 34: 257.

Braverman, Harry. 1998. Labor and Monopoly Capital: The Degradation of Work in the Twentieth Century. New York: Monthly Review Press.

Brown, Roger and Helen Carasso. 2013. Everything for Sale? The Marketisation of UK Higher Education. Abingdon: Routledge.

Bryson, Colin. 2004. „What about the workers? The Expansion of higher education and the transformation of academic work." Industrial Relations Journal 35/1: 38-57.

Caffenzis, George. 2008. „From the Grundrisse to Capital and beyond: Then and now.” Workplace 15: 59-74.

Clarke, Simon. 1991. Marx, Marginalism and Modern Sociology. From Adam Smith to Max Weber. Basingstoke: Palgrave Macmillan.

Clarke, Simon. 2004. „The Neoliberal Theory of Society.” W Neoliberalism. A Critical Reader, red. Alfredo Saad-Filho i Deborah Johnston. London-Ann Arbor: Pluto Press.

Cleaver, Harry. 2012. „Praca w szkole i walka przeciwko pracy w szkole.” Tłum. Iwo Czyż. Preeglad Anarchistyczny 13: 29-67.

Cross, John G. iEdie N. Goldenberg. 2009. Off-Track Profs: Nontenured teachers in Higher Education. Cambridge-London: MIT Press.

Dyer-Witheford, Nick. 1999. Cyber-Marx: Cycles and Circuits of Struggle in High-Technology Capitalism. Urbana-Chicago: University of Illinois Press.

Dyer-Witheford, Nick. 2005. „Cognitive Capitalism and the Contested Campus.” European Journal of Higher Arts Education 2: 71-93.

Fitzgerald, Tanya, Julie White i Helen Gunter. 2012. Hard Labour? Academic Work and the Changing Landscape of Higher Education. Binglay: Emerald Books.

Fuchs, Christian. 2014. Digital Labour and Karl Marx. Abingdon: Routledge.

Gill, Rosalind. 2009. „Breaking the silence: The hidden injuries of neo-liberal academia.” W Secrecy and Silence in the Research Process: Feminist Reflections, red. Róisín Flood i Rosalind Gill. Abingdon: Routledge.

Gulli, Bruno. 2009. „Knowledge Production and the Superexploitation of Contingent Academic Labor." Workplace 16: 1-30.

Hall, Richard. 2013. „Educational technology and the enclosure of academic labour inside public higher education.” Journal for Critical Education Policy Studies 11/3: 52-82. 
Harney, Stefano i Frederick Moten. 1998. „Doing Academic Work.” W Martin, Randy, Chalk Lines. The Politics of Work in the Managed University. Durham-London: Duke University Press.

Harvie, David. 2006. „Value production and struggle in the classroom: Teachers within, against and beyond capital." Capital and Class 30/1: 1-32.

Harvie, David i Massimo De Angelis. 2009 „CCognitive Capitalism’ and the Rat-Race: How Capital Measures Immaterial Labour in British Universities." Historical Materialism 17: 3-30.

Haug, Wolfgang Fritz. 2009. „Immaterial Labour.” Historical Materialism 17/4: 177-185.

Herman, Deborah M. i Julie M. Schmid. 2003. Cogs in the Classroom Factory. The Changing Identity of Academic Labour. Westport: Praeger Publishers.

Iljenkow, Evald. 1982. The Dialectics of the Abstract and the Concrete in Marx's Capital. Tłum. Sergei Kuzyakov. Moscow: Progress Publishers.

Jappe, Anselm. 2013. „Sohn-Rethel and the Origin of 'Real Abstraction': A Critique of Production or a Critique of Circulation?" Historical Materialism 21/1: 3-14.

Johnson, Benjamin, Patrick Kavanagh i Kevin Mattson. 2003. Steal This University. The Rise of the Corporate University and the Academic Labour Movement. Abingdon: Routledge.

Kinman, Gail and Siobhan Wray. 2013. Higher stress. A Survey of stress and well-being among staff in bigher education.

http://www.ucu.org.uk/media/pdf/4/5/HE_stress_report_July_2013.pdf

Krause, Monika, Mary Nolan, Michael Palm i Andrew Ross. 2008. The University Against Itself: The NYU Strike and the Future of the Academic Workplace. Philadelphia: Temple University Press.

Martin, Randy. 1998. Chalk Lines. The Politics of Work in the Managed University. DurhamLondon: Duke University Press.

Mattson, Kevin. 2000. „The Academic Labor Movement: Understanding Its Origin and Current Challenges." Social Policy 30/4: 4-10.

Marks, Karol i Fryderyk Engels. 1961. „Ideologia niemiecka.” W Marks, Karol i Fryderyk Engels, Drieła, t. 3. Warszawa: Książka i Wiedza.

Marks, Karol. 1986. Zarys krytyki ekonomii politycznej. Tłum. Zygmunt Jerzy Wyrozembski. Warszawa: Książka i Wiedza.

Marks, Karol. 1966. „Przyczynek do krytyki ekonomii politycznej.” W Marks, Karol i Fryderyk Engels, Drieła, t. 13. Warszawa: Książka i Wiedza.

Marks, Karol. 1968. „Kapitał. Krytyka ekonomii politycznej. Księga I: »Proces wytwarzania kapitału«." Tłum. Paweł Hoffman, Bronisław Minc i Edward Lipiński. W Marks, Karol i Fryderyk Engels, Dzieła, t. 23. Warszawa: Książka i Wiedza.

Marks, Karol. 1975. „Marks do Engelsa, 24 sierpnia 1967 r.” W Marks, Karol i Fryderyk Engels, Drieła, t. 31. Warszawa: Książka i Wiedza.

Marks, Karol. 1978. „The Value-Form.” Capital and Class 4: 130-150.

Marks, Karol. 1982. „Kapitał. Krytyka ekonomii politycznej. Księga III: »Proces produkcji kapitalistycznej jako całość«.” Tłum. Edward Lipiński, Julian Maliniak. W Marks, Karol i Fryderyk Engels, Drieła, t. 25, cz. 2. Warszawa: Książka i Wiedza. 
Marks, Karol. 1984. Kapitał. Krytyka ekonomii politycznej. Księga III: »Proces produkcji kapitalistycznej jako całość«.” Tłum. Edward Lipiński, Julian Maliniak. W Marks, Karol i Fryderyk Engels, Drieła, t. 25, cz. 1. Warszawa: Książka i Wiedza.

Marks, Karol. 1988. „Economic Works, 1861-1863”. W Marks, Karol i Fryderyk Engels, Collected Works, t. 30. London: Lawrence and Wishart Ltd.

Molesworth, Mike, Richard Scullion i Elizabeth Nixon. 2010. The Marketisation of Higher Education and the Student as Consumer. Abingdon: Routledge.

Moten, Fred i Stefano Harney. 1999. „The academic speed-up.” Workplace 4: 23-28.

Neary, Michael i Ana C. Dinerstein. 2002. The Labour Debate: An Investigation into the Theory and Reality of Capitalist Work. Farnham: Ashgate Publishing Company.

Neary, Mike i Joss Winn. 2009. „The student as producer: reinventing the student experience in higher education." W The future of higher education: policy, pedagogy and the student experience, red. Les Bell, Howard Stevenson i Mike Neary. London-New York: Continuum.

Neary, Mike i Andy Hagyard. 2010. „Pedagogy of Excess: An Alternative Political Economy of Student Life." W The Marketisation of Higher Education and the Student as Consumer, red. Mike Molesworth, Richard Scullion i Elizabeth Nixon. Abingdon: Routledge.

Neary, Mike. 2012. „Beyond Teaching in Public: The University as Form of Social Knowing.” W Towards Teaching in Public. Reshaping the Modern University, red. Les Bell, Howard Stevenson i Mike Neary. London-New York: Continuum.

Nelson, Cary. 1997. Will Teach For Food. Academic Labor in Crisis. Minneapolis: University of Minnesota Press.

Ogbonna, Emmanuel i Lloyd C. Harris. 2004. „Work Intensification and Emotional Labour among UK University Lecturers: An Exploratory Study." Organization Studies 25: 1185.

Pekkola, Elias. 2013. „Academic Work Revised: From Dichotomies to a Typology.” Workplace 22: 1-12.

Peters, Michael, Bulut. Ergin. 2011. Cognitive Capitalism, Education, and Digital Labor. New York: Peter Lang Publishing.

Postone, Moishe. 1980. „Anti-Semitism and National Socialism: Notes on the German Reaction to »Holocaust«." New German Critique 19/1: 97-115.

Postone, Moishe. 1993. Time, Labour and Social Domination. Cambridge: Cambridge University Press.

Postone, Moishe. 2005. „Interview with Moishe Postone by Salih Selcuk.” Krisis. http://www.krisis.org/2005/critical-theory-of-capitalism-today

Postone, Moishe. 2006. „History and Helplessness: Mass Mobilization and Contemporary Forms of Anticapitalism". Public Culture 18/1: 93-110.

Postone, Moishe. 2012. „Exigency of Time: A Conversation with Harry Harootunian and Moishe Postone." Concentric: Literary and Cultural Studies 38/2: 7-43.

Rhoades, Gary. 1998. Managed Professionals: Unionized Faculty and Restructuring Academic Labour. New York: State University of New York Press.

Rikowski, Glenn. 2002. „Fuel for the Living Fire: Labour Power!” W The Labour Debate: An Investigation into the Theory and Reality of Capitalist Work, red. Mike Neary i Ana C.

Dinerstein. Farnham: Ashgate Publishing Company. 
Rosdolsky, Roman. 1977. The Making of Marx's Capital. London-Ann Arbor: Pluto Press.

Scholz, Trebor. 2013. Digital Labour: The Internet as Playground and Factory. Abingdon: Routledge.

Sennett, Richard. 2007. Korozja charakteru. Osobiste konsekwencje pracy w nowym kapitalizmie. Tłum. Jan Dierzgowski i Łukasz Mikołajewski. Warszawa: wydawnictwo Literackie MUZA SA.

Shattock, Michael. 2012. Making Policy in British Higher Education: 1945-2011. Maidenhead: Open University Press.

Shaw, Claire i Lucy Ward. 2014. „Dark thoughts: why mental illness is on the rise in academia." The Guardian, 6 marca. http://www.theguardian.com/higher-educationnetwork/2014/mar/06/mental-healthacademics-growing-problem-pressure-university

Slaughter, Sheila i Larry L. Leslie. 1999. Academic Capitalism: Politics, Policies and the Entrepreneurial University. Baltimore: John Hopkins University Press.

Smyth, John. 1995. Academic Work. The changing labour process in higher education. Buckingham: SRHE i Open University Press.

Sohn-Rethel, Alfred. 1978. Intellectual and Manual Labour. New Jersey: Humanities Press.

Tancred-Sherrif, Peta. 1985. „Craft, hierarchy and bureaucracy: modes of control of the academic labour process." The Canadian Journal of Sociology 10/4: 369-390.

Tight, Malcolm. 2000. Academic Work and Life: What it is to be an academic, and how this is changing. London: JAI Elselvier Science.

UCU. 2013. „Over half of universities and colleges use lecturers on zero hours contracts”. News $5^{\text {th }}$ September. Retrieved on June 2nd 2014 from http://www.ucu.org.uk/6749

Wexler, Steven. 2008. „(I'm)Material labor in the digital age.” Workplace 15: 1-11.

Whitchurch, Celia i George Gordon. 2010. Academic and Professional Identities in Higher Education: The Challenges of a Diversifying Workforce. Abingdon: Routledge.

Willmott, Hugh. 1995. „Managing the Academics: Commodification and Control in the Development of University Education in the UK." Human Relations 48/9: 993-1027.

Wilson, Tom. 1991. „The proletarianisation of academic labour.” Industrial Relations Journal 22/4: 250-262.

Winn, Joss. 2013. „Hacking in the university: Contesting the valorisation of academic labour." Triple C: Communication, Capitalism and Critique 11/2: 486-503. 
Joss Winn - starszy wykładowca w College of Social Science oraz School of Education, University of Lincoln oraz członek założyciel kooperatywnej instytucji szkolnictwa wyższego Social Science Centre, mającego siedzibę w Lincoln w Wielkiej Brytanii. Jego badania poświęcone są szeroko rozumianej krytyce ekonomii politycznej szkolnictwa wyższego. Jego badania i dydaktyka skupiają się obecnie na historii i ekonomii politycznej nauki oraz technologii w szkolnictwie wyższym, jej znaczenia dla pracy akademickiej i wpływu tej pracy na nia, jak również na sposobach, w jakie akademicy moga kontrolować środki produkcji wiedzy poprzez kooperatywne, a ostatecznie postkapitalistyczne formy pracy i demokracji. Publikował m.in. w Workplace, triple C czy Policy Futures in Education. Obecnie przygotowuje numer tematyczny czasopisma Workplace (wspólnie z Karen Gregory) „, Marx, Engels and the critique of academic labour” oraz książkę (wspólnie z Richardem Hallem).

\section{DANE ADRESOWE:}

University of Lincoln

Lincoln LN6 7TS

EMAIL: jwinn@lincoln.ac.uk

CYTOWANIE: Winn, Joss. 2015. „Pisanie o pracy akademickiej.” Praktyka Teoretyczna 4 (18): $20-43$.

DOI: $10.14746 /$ prt.2015.4.1

\section{AUTHOR: Joss Winn}

TITLE: Writing About Academic Labour

ABSTRACT: This essay calls for a return to the labour theory of Marx, or rather to Marx's negative critique of labour and its "pivotal" role in comprehending the political economy of higher education. It argues that a critique of capitalism and its apparent complexity must be undertaken through an immanent critique of labour, rather than from the standpoint of labour as has been the case in both Marxist and non-Marxist traditions of labour studies. Through a review of exemplar articles on 'academic labour', the essay draws attention to the fundamental importance of employing Marx's method of abstraction so as to understand the concrete social world of capital. Finally, it proposes that the future of academic labour is to be found in its negation and overcoming rather than in efforts to resist the 'logic' of valorisation.

KEYWORDS: Marx, abstraction, method, labour, negative critique 